\title{
Role of Curcumin in Retinal Diseases-A review
}

\author{
Priya R. Chandrasekaran ${ }^{1}$ - V. G. Madanagopalan ${ }^{2}(\mathbb{0}$
}

Received: 9 October 2021 / Revised: 21 December 2021 / Accepted: 27 December 2021 / Published online: 11 January 2022

(c) The Author(s), under exclusive licence to Springer-Verlag GmbH Germany, part of Springer Nature 2022

\begin{abstract}
Purpose To review the role of curcumin in retinal diseases, COVID era, modification of the molecule to improve bioavailability and its future scope.

Methods PubMed and MEDLINE searches were pertaining to curcumin, properties of curcumin, curcumin in retinal diseases, curcumin in diabetic retinopathy, curcumin in age-related macular degeneration, curcumin in retinal and choroidal diseases, curcumin in retinitis pigmentosa, curcumin in retinal ischemia reperfusion injury, curcumin in proliferative vitreoretinopathy and curcumin in current COVID era.

Results In experimental models, curcumin showed its pleiotropic effects in retinal diseases like diabetic retinopathy by increasing anti-oxidant enzymes, upregulating HO-1, nrf2 and reducing or inhibiting inflammatory mediators, growth factors and by inhibiting proliferation and migration of retinal endothelial cells in a dose-dependent manner in HRPC, HREC and ARPE-19 cells. In age-related macular degeneration, curcumin acts by reducing ROS and inhibiting apoptosis inducing proteins and cellular inflammatory genes and upregulating HO-1, thioredoxin and NQO1. In retinitis pigmentosa, curcumin has been shown to delay structural defects of $\mathrm{P} 23 \mathrm{H}$ gene in $\mathrm{P} 23 \mathrm{H}$-rhodopsin transgenic rats. In proliferative vitreoretinopathy, curcumin inhibited the action of EGF in a dose- and time-dependent manner. In retinal ischemia reperfusion injury, curcumin downregulates IL-17, IL-23, $\mathrm{NF}_{\mathrm{K}} \mathrm{B}$, STAT-3, MCP-1 and JNK. In retinoblastoma, curcumin inhibits proliferation, migration and apoptosis of RBY79 and SO-RB50. Curcumin has already proven its efficacy in inhibiting viral replication, coagulation and cytokine storm in COVID era.

Conclusion Curcumin is an easily available spice used traditionally in Indian cooking. The benefits of curcumin are manifold, and large randomized controlled trials are required to study its effects not only in treating retinal diseases in humans but in their prevention too.
\end{abstract}

\section{Key messages}

- Curcumin-Its pleotropic effect in Gastrointestinal disorders, Cardiovascular disorders, Neurodegenerative disorders, Rheumatological disorders, Anti-cancer drug are known.

- Curcumin-COVID era -Anti-viral, Immunomodulatory, Anti-inflammatory, Anti-Coagulatory effect

- Curcumin -Its role and mechanism in Diabetic Retinopathy, Age Related Macular Degeneration, Retinitis Pigmentosa and Proliferative Vitreoretinopathy.

- Curcumin -Its role and mechanism in Retinal Ischemia and Reperfusion Injury, Retinoblastoma, Methyl alcohol poisoning and Best Dystrophy.

- Curcumin-Improving bioavailability.

Keywords Curcumin $\cdot$ Diabetic Retinopathy $\cdot$ Age-Related Macular Degeneration $\cdot$ Retinitis Pigmentosa $\cdot$ Retinal Ischemia Reperfusion Injury

Priya R. Chandrasekaran

priya_rc@rediffmail.com

Extended author information available on the last page of the article 


\section{Introduction}

Retinal ganglion cells (RGCs) and photoreceptors in retina are vulnerable to oxidative stress leading to reactive oxygen intermediates (ROI) production. Aging, irradiation, inflammation, air pollutants, cigarette smoke, etc., produce ROI. ROI includes free radicals, singlet oxygen and hydrogen peroxide. Free radicals include superoxide anion, hydroxyl free radicals, hydroperoxyl radicals and lipid peroxyl radicals. All these add to oxidative stress, which causes the imbalance of the anti-oxidant system (Vitamins A, C, E, beta carotene, superoxide dismutase, glutathione peroxidase, catalase, zinc and selenium), which leads to lipid peroxidation, DNA fragmentation, protein crosslinking, fragmentation, proteolysis and cell necrosis and apoptosis. Anti-oxidant enzymes are present in photoreceptors and retinal pigment epithelium (RPE) [1].
Reasons for retina being vulnerable to oxidative stress and thereby generate ROI stem from the fact that retina consumes much more oxygen than any other tissue, poly unsaturated fatty acid-rich photoreceptor outer segments can get oxidized and initiate the cytotoxic cycle, RPE and neuro sensory retina have photosensitizers (melanin, rhodopsin, lipofuscin and cytochrome $\mathrm{C}$ oxidase and blood-borne sensitizers like protoporphyrin IX), oxidative stress induced by phagocytosis by the RPE and lastly, retina being subjected to cumulative radiation [1].

Pathway for cellular damage following oxidative stress is depicted in Fig. 1.

Lot of natural products like carotenoids (lutein and zeaxanthin [2]), catechin [3], saffron [4] and ginkgo biloba [5] products have shown greater potential in normalizing diabetes-induced histological, biochemical and functional changes in diabetic rats and neuroprotective effect in retinal degenerative diseases in animal models. Curcumin is a spice that has established its effects in rheumatological
Fig. 1 Pathway for cellular damage following oxidative stress

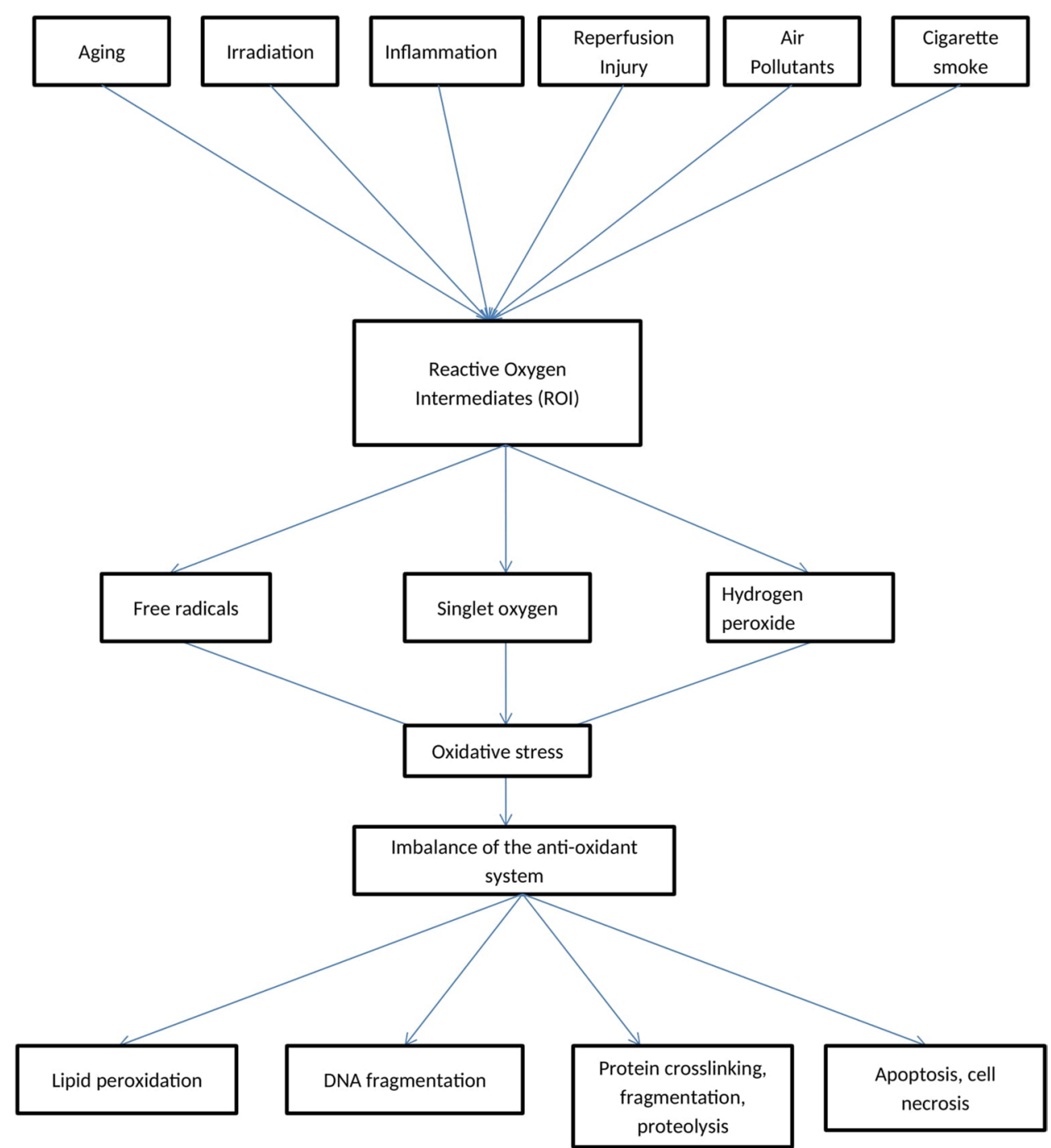


disorders, rhinitis, gastrointestinal disorders [6], cardiovascular disorders [7], stroke, Parkinson's disease, Alzheimer's disease [8] and certain cancers (brain, lung, breast and colon cancer) [9]. Lately, curcumin has captivated the attention of researchers in retinal disorders owing to its already established therapeutic effects in other systemic diseases.

This review article showcases the biochemical properties, pharmacological properties of curcumin and their possible beneficial role in treating retinal disorders.

\section{Methods}

PubMed and MEDLINE searches were pertaining to curcumin, properties of curcumin, curcumin in retinal diseases, curcumin in diabetic retinopathy, curcumin in age-related macular degeneration, curcumin in retinal and choroidal diseases, curcumin in retinitis pigmentosa, curcumin in retinal ischemia reperfusion injury, curcumin in proliferative vitreoretinopathy and curcumin in current COVID era.

\section{Structure and chemical properties of curcumin}

Curcumin is a curcuminoid obtained from turmeric (curcuma longa) that belongs to the Zingiberaceae family. They belong to the group of phytocompounds that are biologically active molecules obtained from plants with positive effects on health. Curcumin is a bis- $\alpha, \beta$-unsaturated $\beta$-diketone with the chemical name 1,7-bis-(4-hydroxy3-methoxyphenyl)1,6-heptadiene-3,5-dione and commonly called diferuloylmethane, E100 (European code of food additives) or Natural Yellow 3. Its chemical formula is $\mathrm{C}_{21} \mathrm{H}_{20} \mathrm{O}_{6}$ and molecular weight is $368.38 \mathrm{gm} / \mathrm{mol}$. It has two aromatic ring systems containing o-methoxy phenolic groups that are linked with a seven-carbon linker consisting of $\alpha, \beta$-unsaturated $\beta$-diketone moiety. It also exists in two tautomeric forms, keto-enol and diketo tautomers. It is present in keto-enol form in polar organic solvents, which is the predominant form of tautomer. Curcumin is hydrophobic, insoluble in water but soluble in methanol, ethanol, chloroform, dimethyl sulfoxide, ethyl acetate and acetonitrile [10-15].

The other curcuminoids include demethoxycurcumin and bis-demethoxycurcumin that have properties similar to curcumin. The most edible part of the plant is its root (rhizome), which is dried and crushed and used as a spice powder, and this powder contains curcumin [10-15].

The anti-inflammatory property of curcumin is by inhibition of TNF-dependent $\mathrm{NF}_{\mathrm{k}} \mathrm{B}$ (tumour necrosis factordependent transcriptional nuclear factor kappa B) and pathways that produce reactive oxygen intermediates. Curcumin downregulates COX-2 (cyclooxygenase-2) that are predominantly seen at the sites of inflammation that mediate pain and inflammatory process. Curcumin inhibits pro-inflammatory enzyme 5-LOX (5-lipoxygenase) that are involved in the biosynthesis of leukotrienes and lipid mediators of inflammation. It also downregulates inflammatory cytokines like TNF, IL-1 (interleukin-1), IL-6, IL-8, iNOS (inducible nitric oxide synthase) and interferon- $\Upsilon$. Curcumin at a dose of $360 \mathrm{mg} /$ dose for 3-4 months in humans reduced clinical relapse in those with quiescent inflammatory bowel disease and decreased the use of concomitant medications [10-16].

The anti-oxidative action of curcumin is mediated through inhibition of stress-induced elevated levels of 8-hydroxydeoxyguanosine and 8-nitroguanine, regulating the activity of mitochondrial respiratory complexes and upregulation of Nrf2 (nuclear factor erythroid-derived 2-related factor 2) that induces haemoxygenase-1 (HO-1) The anti-oxidant activity of curcumin is predominantly due to the hydroxyl group [17-19]. Rats that were pre-treated with daily dose of intragastric curcumin $(200 \mathrm{mg} / \mathrm{kg}$ for 7 days $)$ prior to induced ischemia and reperfusion showed attenuation of mitochondrial lipid peroxidation and alterations in oxygen consumption along with prevention of decrease in GSH, SOD and GR (glutathione reductase) activity [17]. Curcumin $(5,10,20$ and $30 \mu \mathrm{M})$ stimulates the expression of $\mathrm{Nrf} 2$ in a concentration- and time-dependent manner, which in turn increases HO-1 expression and HO-1 activity, which is a redox-sensitive inducible protein that protects from various forms of stress in cultured renal epithelial cells from rats. It stimulates ARE (antioxidant responsive elements) binding activity in NRK cells from rat kidney [19]. Sreejayan et al. showed that curcumin at a dose of $25 \mu \mathrm{M}$ reduced nitrite production from incubated solution of sodium nitroprusside in phosphate-buffered saline. The scavenging of nitric oxide (NO) by curcumin was concentration-dependent (50\% at 20.4 and $100 \%$ at $50 \mu \mathrm{M}$ ). Curcumin was shown not to interact with nitrite detection assay or directly interact with nitrite. All forms of curcumin-demethoxy curcumin, bisdemethoxy curcumin and diacetyl curcumin—had NO scavenging property irrespective of the methoxy or the phenolic group [20].

Histone acetyltransferases (HAT) and p300/CBP (cyclic adenosine monophosphate response element binding protein) have been linked to degenerative diseases, diabetes and certain cancers. Curcumin (up to $30 \mu \mathrm{M}$ for $8 \mathrm{~h}$ ) reduces the levels of $\mathrm{p} 300 / \mathrm{CBP}$ in a dose-dependent manner in vivo. At concentrations 10-100 $\mu \mathrm{M}$, curcumin inhibits histone acetylation by causing proteasome-dependent degradation of p300 and CBP in vitro [21].

The anti-tumour activity of curcumin is mediated via anti-inflammatory, apoptosis-inducing, anti-oxidative and anti-angiogenic activities. In colon cancers, the antitumour activity of curcumin was mediated via inhibition 
of COX-2. P53 (apoptosis-inducing in stressful situations) has been shown to have a varied response to curcumin administration; overexpression in human hepatoblastoma, human breast cancer cells and human basal cell carcinoma and downregulation in colorectal carcinoma reveal that it may be tissue-specific [10]. Its anti-angiogenic effect is by inhibition of angiogenic factors like fibroblast growth factor (FGF), ligands of VEGF and angiopoietin 1 and 2 and regulation of cell adhesion molecules like endothelial adhesion molecule-1 (ELAM-1), intracellular adhesion molecule-1 (ICAM-1), vascular cell adhesion molecule-1 (VCAM-1) and cell surface proteins that are involved in tumour metastasis [22].

\section{Limitations of curcumin}

Curcumin has been described as PAINS (Pan-assay interference compounds) and IMPS (invalid metabolic panaceas) for producing disproportionate amount of hits and mostly false positives. These questions were raised based on the suspicion regarding its properties [23, 24]. Curcumin had low solubility in aqueous medium and disintegrated into different compounds in physiological conditions raising questions about the actual bioactive form responsible for its actions. There were products in the name of turmeric, turmeric extract, curcuminoid-enriched turmeric extract, curcumin-enriched materials and curcumin itself. Curcuminoid-enriched turmeric extract showed key materials like purcumin (purified curcumin), purcuminoids (purified demethoxycurcumin, bisdemethoxycurcumin), lipophilic metabolites and hydrophilic metabolites. There were concerns regarding the purity of the compound that were used in clinical trials. The need for high levels of this compound (>3.6 gm/day in humans) to achieve therapeutic benefits was another concern [13].

\section{Modifications of the molecule to overcome the limitations}

\section{Encapsulation}

Curcumin carriers like nanoparticles [25] and liposomes [26] were able to make bioavailability, solubility and stability better in an aqueous medium. Another delivery form of curcumin was the amphiphilic polymer (Soluplus), which had both hydrophilic and lipophilic component [25, 27]. A bio-degradable form of curcumin-loaded scleral plug showed promising results in posterior segment diseases in rabbit eyes both in vitro and in vivo [28]. Curcumin-phospholipid lecithin formulation in the name of Meriva has shown improvement in visual acuity and macular oedema in DR patients when administered twice daily [29].

Granata et al. used micellar nano-aggregate calix $\{4\}$ arene as a nano-carrier for ocular use and reported that the solubility of curcumin increased by 9000 -fold, stability by 7.5 times and efficacy better than curcumin in reducing ocular inflammation [30]. Davis et al. used a nano-carrier containing TPGS (d-ó-tocopheryl polyethylene glycol 1000 succinate) and Pluronic acid F127 for topical in eye diseases and reported that the solubility of curcumin increased by a factor of 4,00,000 and greater neuroprotective effect against glutamate and preservation of RGC in murine models [31]. Another carrier for curcumin was a thermosensitive chitosan gelatin-based hydrogel formulation in combination with latanoprost increased bioavailability for glaucoma [32]. Kim et al. used albumin-based nano-formulation to increase the solubility [33]. Another formulation in the form of tetrahydrocurcumin (THC) and cyclodextrin form showed excellent bioavailability and greater anti-oxidant activity in rabbit corneas and retinas [34].

\section{Curcumin analogues}

The stability and bioavailability of curcumin can be enhanced by using its pro-drug dephosphorylated curcumin (Cur-2p) and curcumin diethyl disuccinate (Cur-DD). Cur$2 p$ showed greater stability and lower aggregation in aqueous media. Cur-DD had the same effect as curcumin in inhibiting apoptosis but with greater safety and protection $[35,36]$. Other analogues like nitric oxide-releasing curcumin (VP10/12) and caffeic acid phenethyl ester (CAPE; VP10/39) decreased reactive oxygen species in a dosedependent manner in ARPE-19 cells (Retinal Pigment Epithelial immortalized cell line from Amy Aotaki-keen eyes) [37]. Bioavailability enhancer like curcumin-piperine considerably increased the curcumin blood levels [38].

\section{Curcumin in retinal diseases}

\section{Diabetic retinopathy (DR)}

Retina, because of its high content of polyunsaturated fatty acids (PUFA), high oxygen and glucose uptake is, vulnerable to oxidative stress. Inflammation is another underlying factor in the pathogenesis of DR. Oxidative stress leads to formation of ROS, which is hypothesized to cause the development of neuropathy, nephropathy, myocardial infarction and retinopathy. Autooxidation of glucose, shift in redox balance, decrease in the concentration of reduced glutathione (GSH-ROS scavenger), vitamin C, Beta carotene and vitamin $\mathrm{E}$ and impairment of antioxidant enzymes like superoxide dismutase (SOD), glutathione reductase, 
glutathione peroxidase and catalase are considered as the possible sources of oxidative stress in diabetes. Retina of diabetic rats shows elevated superoxide and hydrogen peroxide $\left(\mathrm{H}_{2} \mathrm{O}_{2}\right)$ levels along with lipid peroxidation and oxidative damage to DNA because of ROS. The other pathways that lead to DR are polyol pathway that depletes nicotinamide adenine dinucleotide phosphate (NADPH) essential for regeneration of GSH, advanced glycosylation end product (AGE) and its receptor RAGE that get deposited in the retinal capillary cells leading to more ROS and activation of $\mathrm{NF}_{\mathrm{K}} \mathrm{B}$ and caspase-3-induced apoptosis and damage to cellular constituents, protein kinase $\mathrm{C}$ (PKC) pathway, which gets activated by increased ROS and diacylglycerol as a result of hyperglycaemia that increase vessel permeability and blood flow, stimulate neovascularization, endothelial proliferation and apoptosis by regulating the action of vascular endothelial growth factor (VEGF), insulin-like growth factor-1 (IGF-1) and transforming growth factor- $\beta$ (TGF- $\beta$ ). ROS also activates hexosamine pathway by inhibiting glyceral- dehyde-3-phosphate dehydrogenase (GAPDH), which further activates AGE pathway and the damage thereafter. ROS causes dysfunction of mitochondria, which leads to superoxide production and free radical damage and mutations in mitochondrial DNA that leads to mitochondrial DNA damage in retina in diabetes. Also, ROS-induced damage to mitochondria suppresses antioxidant-mediated effective scavenging of ROS. Exposure of pericytes and endothelial cells shows an increase in caspase- 3 activity, oxidative stress and transcription factors that leads to capillary cell death. Photoreceptors, Muller cells, ganglion cells and astrocytes are affected and are involved in the pathogenesis of DR [39].

Figure 2 shows various pathways leading to pathogenesis in DR.

Chiu et al. reported that chronically elevated blood glucose levels lead to oxidative stress and activation of poly (ADP-ribose) polymerase (PARP), a nuclear enzyme activated by DNA strand, which in turn upregulates the levels of endothelin-1 in target organs like

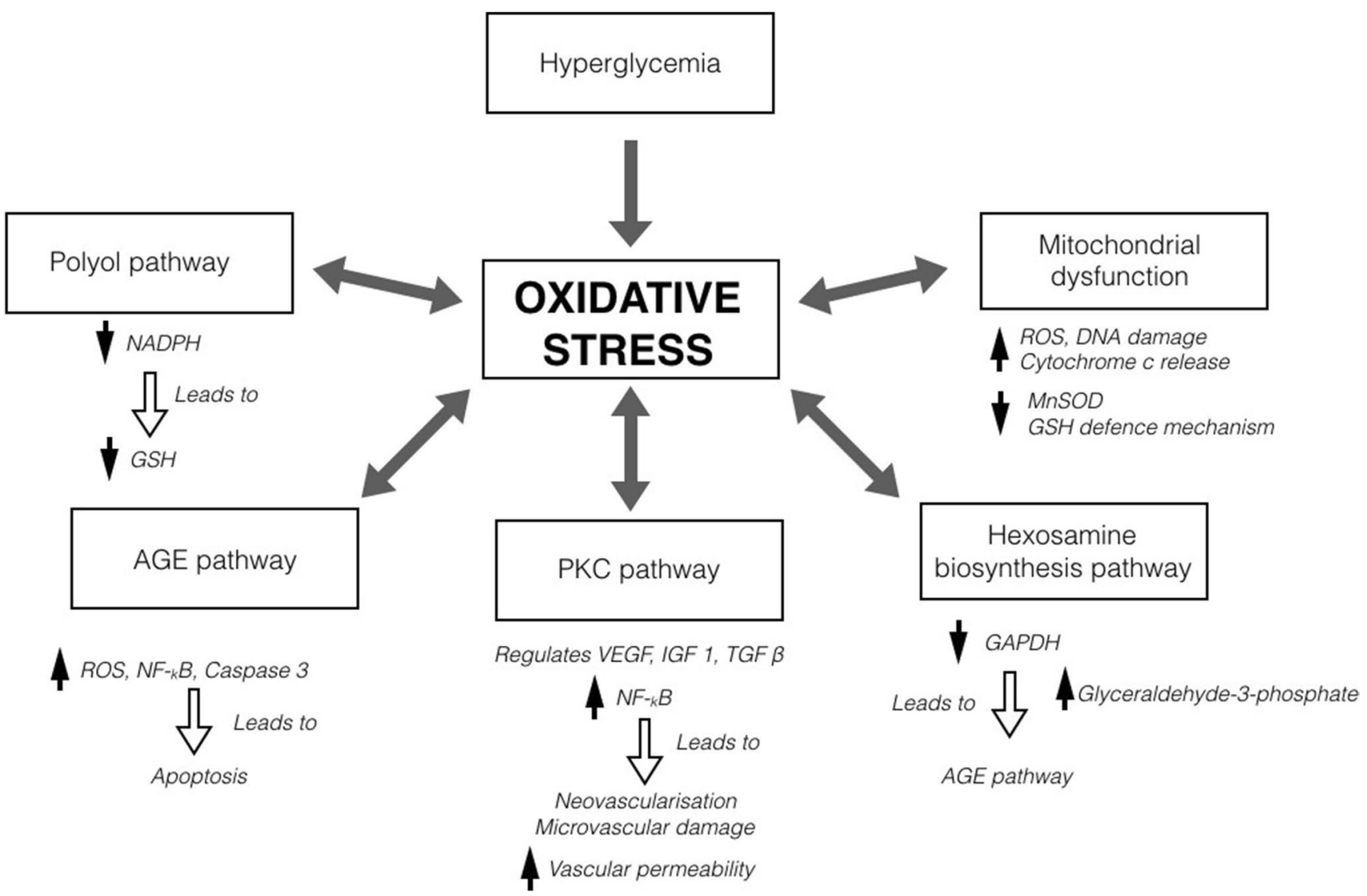

Fig. 2 Various pathways leading to pathogenesis in DR (NADPHnicotinamide adenine dinucleotide phosphate, GSH-Glutathione, AGE-advanced glycosylation products, ROS—reactive oxygen species, $\mathrm{NF}_{\mathrm{K}} \mathrm{B}$-nuclear factor kappa-light chain enhancer of activated
B cells, PKC - protein kinase C, VEGF - vascular endothelial growth factor, IGF-1-insulin-like growth factor-1, TGF- $\beta$ - transforming growth factor- $\beta$, MnSOD-manganese superoxide dismutase, GAPDH - glyceraldehyde-3-phosphate dehydrogenase 
retina, kidney and heart, and increased extracellular matrix protein production like fibronectin and diabetic complications. This was averted in streptozotocininduced rats by using PARP inhibitor, which not only reduced oxidative stress and its damage but also prevented PARP-induced activation of endothelin- 1 and fibronectin [40].

Table 1 gives the effect of curcumin in various in vitro and in vivo studies at various stages of DR.

ARPE-19 cells—spontaneously arising human RPE cell line derived from Ami-Aotaki keen from normal eyes-have structural and functional properties characteristic of RPE cells in vivo and are used to study retinal cell biology, pathological conditions and pharmacology in vitro.

HREC-Human retinal endothelial cells are isolated from human healthy retina, negative for HIV, $\mathrm{HCV}$, mycobacteria and fungi and can be used only for research in vitro and not for animal or human use or for diagnostic procedures in vitro.

Thus, curcumin shows its effects in a dose-dependent manner through various mechanisms at various levels both in vitro and in vivo.

\section{Age-related macular degeneration (AMD)}

Mandal et al. evaluated curcumin for the management of light-induced retinal degeneration (LIRD) in rats that were reared using $5 \mathrm{~lx}$ dim light. These rats were fed with purified and crystalline curcumin $0.2 \%(2000 \mathrm{ppm})$ for 2 weeks. Rats were exposed to 1000 lx light (white cool light) for $3 \mathrm{~h}$ only in the left when right eye served as control. ERG was performed 5-7 days later, which showed preservation of scotopic a wave, $b$ wave and photopic $b$ wave amplitudes which was reduced $(40 \%)$ in controls. Superior and inferior outer nuclear layer thickness (ONL) was grossly reduced (37\% vs $27 \%$ ) in uncovered eyes and covered eyes in controls, while curcumin-treated uncovered eyes showed $21 \%$ and $19 \%$, respectively. Curcumin reduced the expression of pro-inflammatory, proapoptotic and oxidative stress-related genes in the retina. Curcumin reduced the levels of nitrotyrosine, a strong oxidant. Curcumin causes inhibition of $\mathrm{NF}_{-}{ }_{\mathrm{K}} \mathrm{B}$ whose activation induces the apoptotic degenerative process and downregulation of cellular inflammatory genes. Pre-treatment with curcumin on retina-derived cell lines (661 W and ARPE-19) showed that curcumin protected these cells from hydrogen peroxide $\left(\mathrm{H}_{2} \mathrm{O}_{2}\right.$-induced cell death by upregulation of cellular protective enzymes like thioredoxin and HO-1 and decreased expression of early growth response protein 1 (EGR-1) and intercellular adhesion molecule -1(ICAM-1) [49].
Chang et al. used patient-derived RPEs from induced pluripotent-induced cells with AMD-associated background and found them to have reduced anti-oxidant ability when compared to normal RPE cells. Pre-treatment with curcumin $(0.1-200 \mu \mathrm{M})$ for $24 \mathrm{~h}$ was given, and cell viability was assessed using methyl thiazyl tetrazolium (MTT) assay. This showed that concentrations above $10 \mu \mathrm{M}$ increased the proliferation of cells and 150 and $200 \mu \mathrm{M}$ reduced cell viability. Curcumin protected against $\mathrm{H} 2 \mathrm{O} 2$-induced cell death in a concentration of $10 \mu \mathrm{M}$ when pre-treatment time was less than 8-12 h. Curcumin reduced and maintained intracellular ROS levels in AMD-RPE cells at varied concentrations $(0.1,1,10 \mu \mathrm{M})$ for $12 \mathrm{~h}$ in $\mathrm{H} 2 \mathrm{O} 2$-exposed cells. Treatment with curcumin showed increase of anti-oxidant genes HO-1, SOD2 (superoxide dismutase 2) and GPX1 (glutathione peroxidase 1) and reduces the expression of VEGF, PDGF (platelet-derived growth factor) and IGFBP 2 (insulin-like growth factor binding protein 2) using RTPCR in RPE-AMD cells. Pre-treatment with curcumin inhibited JNK pathway that involves a series of inflammatory pathways leading to cell death in RPE-AMD cells. Thus, curcumin may potentially be an ideal drug in restoring the function in AMD patient-derived RPE cells [50].

Park et al. studied the protective effects of curcumin in A2E-accumulated ARPE-19 cells that were exposed to blue light to induce cytotoxicity. A2E and iso-A2E are main pigments of lipofuscin that accumulate in RPE and cause RPE cell death in AMD. Exposure to blue light on A2E-accumulated RPE causes upregulation of transcription factors such as P53, c-Abl, which in turn causes antiapoptotic effect by upregulating JNK (c-Jun N-terminal kinases). Curcumin and curcuminoids extract contained $72.53 \%$ of curcumin, $17.56 \%$ of dimethoxy curcumin and $9.45 \%$ of bisdemethoxy curcumin. Protective effects of curcumin and curcuminoids were observed in a dose-dependent manner with curcumin being $10.46 \%, 24.89 \%$ for 10 and $15 \mu \mathrm{M}$ concentrations, demethoxycurcumin being $11.92 \%$, $28.80 \%$ and $34.10 \%$ for 10,15 and $20 \mu \mathrm{M}$ concentration and bisdemethoxycurcumin being $12.53 \%$ and $32.56 \%$ for 15 and $20 \mu \mathrm{M}$ concentration. Protective effect was seen at $15 \mu \mathrm{M}$ in all three forms, and at doses more than $20 \mu \mathrm{M}$, the protective effect was lost and cell viability decreased showing the toxic nature of curcumin at higher doses. All three of them significantly lowered the mRNA expression of c-Abl and p53 and more with dimethoxy curcumin [51].

Bhattacharjee et al. described similar pathogenesis in AMD and certain neurological disorders which demonstrated that accumulation of $\beta$ amyloid peptide 42 (A $\beta 42)$ and the inability to clear these self-aggregating 


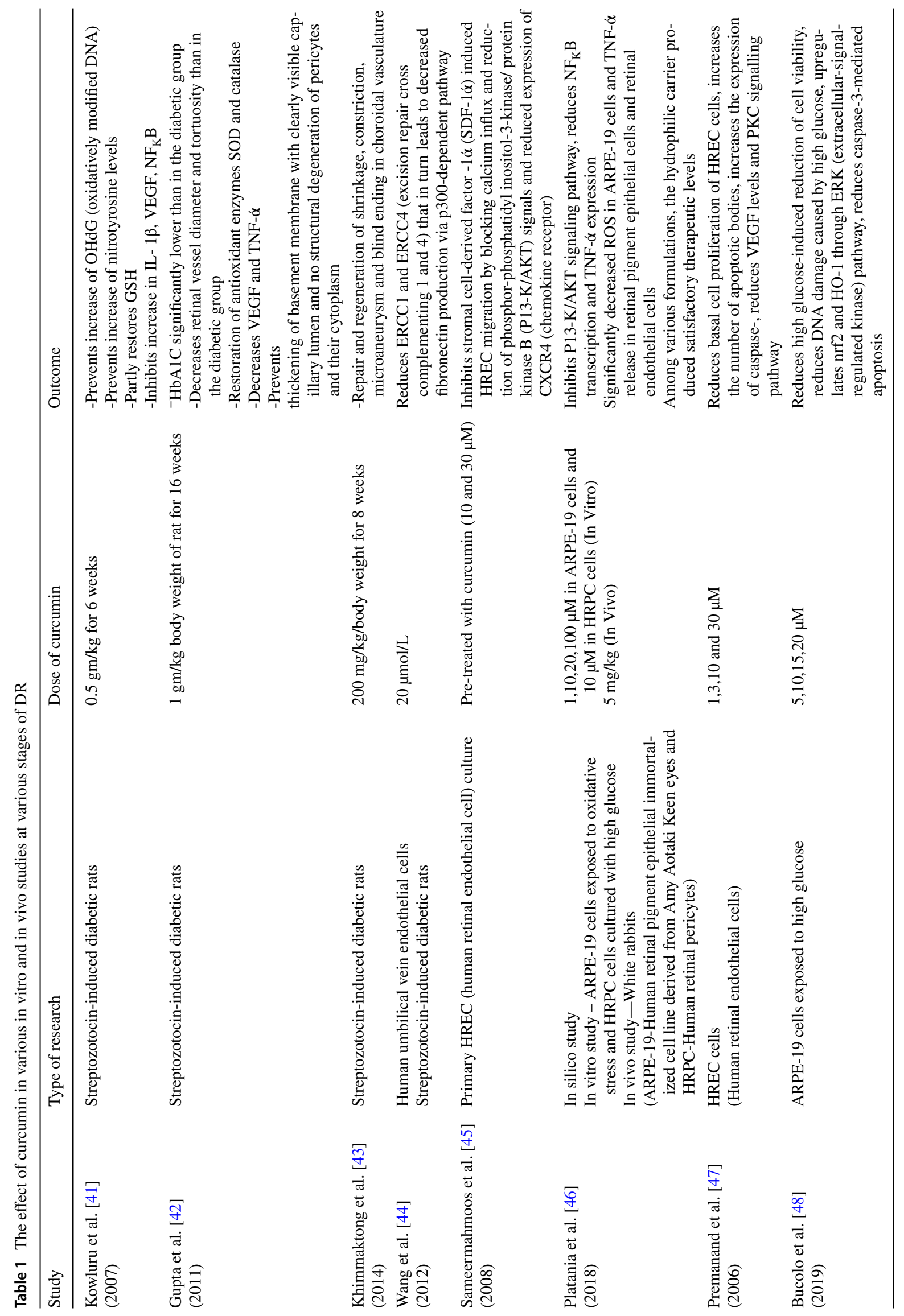


peptides in part form the basis of drusen and AMD pathogenesis. TREM-2 (triggering receptor expressed on myeloid cells/microglial cells-2) is responsible for clearing $\mathrm{A} \beta 42$ peptides in AMD retina and oxidatively stressed microglial cells in central nervous system. This was mediated via upregulation of $\mathrm{NF}_{\mathrm{K}} \mathrm{B}$-sensitive miRNA34a (micro-RNA34a) that downregulated TREM-2 which compromised the phagocytic process. Human post-mortem retinal tissues and cultured C8B4 microglial cells (one week old) in which ROS was induced using $\mathrm{H} 2 \mathrm{O} 2$. These were further treated with phenyl butyl nitrone (PBN), resveratrol analogue, caffeic acid ester and curcumin, before adding $\mathrm{NF}_{\mathrm{K}} \mathrm{B}$ containing miRNA34a, and observed that all of them lowered ROS-induced IL-1 $\beta$ and TNF- $\alpha$ mediated induction of miRNA34a and restored TREM-2. This formed the basis of anti- $\mathrm{NF}_{\mathrm{K}} \mathrm{B}$ and anti- miRNA34a therapeutic strategy for upregulating TREM-2 [52].

Kakouri et al. used $200 \mathrm{mg}$ of resveratrol, $240 \mathrm{mg}$ for quercetin and $2000 \mathrm{mg}$ of curcumin per day for 12 months in patients with advanced (9 patientshyperfluorescent area of macular atrophy greater than $0.15 \mathrm{~mm}^{2}$ and hyperreflectivity in the choroidal region by OCT) and nascent ( 3 patients-area of macular atrophy not greater than $0.015 \mathrm{~mm}^{2}$ ) geographic atrophy (GA). Fundus autofluorescence and Spectralis OCT were performed at 3 monthly intervals, and growth rate was measured in $\mathrm{mm}^{2}$ /year and square-root-transformed mm/year. For advanced $\mathrm{GA}$, the annual growth rate was $0.35 \pm 0.66 \mathrm{~mm}^{2} /$ year (square-root-transformed $0.10 \pm 0.11 \mathrm{~mm} / \mathrm{year}$ ) and that of nascent GA was $0.01 \pm 0.02 \mathrm{~mm}^{2} /$ year (squareroot-transformed $0.02 \pm 0.03 \mathrm{~mm} /$ year) which were significantly less when compared to the results published by Yehoshua et al., which was $1.20 \pm 0.9 \mathrm{~mm}^{2} /$ year (square-root-transformed $0.18 \mathrm{~mm} /$ year) with curcumin $(\mathrm{P}=0.003)$ [53].

Barry et al. used curcumin (diaryl heptanoid $-1330 \mathrm{mg}$ twice daily for 6 months) as a naturally fluorescent probe for in vivo visualization of $\beta$-amyloid (present in macular drusen in AMD patients) and determine and quantitate the time course of curcumin fluorescent labelling of drusen. Using an interactive cursor outline and spot analysis (to determine fluorescence), individual drusen was identified, segmented, thresholded and analysed. Patients demonstrated increased curcumin fluorescence at 2, 4 and 6 months at the fovea, thereby demonstrating drusen fluorescence over time. Absence of fluorescence indicated disappearance of $\beta$-amyloid in drusen. Thus, progression of drusen and progression to late forms of AMD might be monitored using curcumin-labelled $\beta$-amyloid [54].
Bielskus et al. used oral curcumin (1330 mg twice daily for 6 months) to evaluate its effect on drusen size in dry AMD and took retinal images at 0, 2, 4 and 6 months after dividing into 2 groups (14/20 in group 1 and 6/20 in group 2). Nineteen belonged to intermediate and 1 was advanced AMD. Change in total drusen volume, total drusen volume threshold of $0.03 \mathrm{~mm}^{3}$ for increased risk of developing late AMD and change of staging. Drusen volume decreased in 11 subjects $(0.110 \pm 0.106-0.055 \pm 0.060, \mathrm{p}=0.004)$, remained stable in $3(0.265 \pm 0.127-0.260 \pm 0.168$, $\mathrm{p}=0.18)$ and increased in $4(0.112 \pm 0.219-$ $0.154 \pm 0.206, p=0.04)$. Mean foveal volume significantly decreased at 6 months $(-14.0 \%, \mathrm{p}<0.0001)$. Staging decreased from intermediate to early AMD in 1 ; volume decreased below the threshold risk volume of $0.03 \mathrm{~mm}^{3}$ and increased above $0.03 \mathrm{~mm}^{3}$ in 2. The same researchers used oral curcumin $2660 \mathrm{mg} /$ day for 1 year in 18 patients with pre-advanced AMD (drusen $\geq 63 \mu \mathrm{m}$ without $\mathrm{CNV}$ or GA). The total mean drusen volume reduced from 0.0204 to 0.0184 $\mathrm{mm}^{3}(\mathrm{p}=0.009)$, foveal drusen volume reduced from 0.0092 to $0.0079 \mathrm{~mm}^{3}(\mathrm{p}=0.030)$, parafoveal volume decreased from 0.0086 to $0.0078 \mathrm{~mm}^{3}(\mathrm{p}=0.10)$ and perifoveal volume increased $(30.9 \%, \mathrm{p}=0.08)$ after 1 year with responders and non-responders being $56 \%$ and $19 \%$, respectively, and no cases of CNV or GA after 1 year [55, 56].

\section{Retinitis pigmentosa (RP)}

In the autosomal dominant form, the mutation in the $\mathrm{P} 23 \mathrm{H}$ gene is associated with the misfolding of the rhodopsin gene which retains this gene within the endoplasmic reticulum and causes subsequent formation of insoluble aggregates which consequentially causes photoreceptor cell death in RP [57]. Vasireddy et al. used COS-7 cells expressing wild type or mutant (P23HR) rhodopsin with V5 tag for analysing the presence of protein aggregates using immunocytochemistry and fluorescent microscopy. Co-expression of wild type and $\mathrm{P} 23 \mathrm{H}-\mathrm{R}$ showed that mutant rhodopsin interacts with wild type to form cytoplasmic inclusions. Treatment with curcumin $(5 \mu \mathrm{M})$ showed reduction of formation of mutant protein aggregates. The bioavailability of curcumin in brain and ocular tissues was assessed using $100 \mathrm{mg} / \mathrm{kg}$ body weight of Sprague-Dawley rats, which showed that oral curcumin crosses blood-brain and blood-retina barriers after $2 \mathrm{~h}$ of oral administration, and the highest amount of curcumin was found in sclera, RPE and optic nerve (0.076-0.079 $\mathrm{ng} / \mathrm{mg}$ tissue weight) and the lowest was found in lens and vitreous (0.003-0.004 ng/mg tissue weight). Transgenic rats that were treated with curcumin from P30-P60 showed preservation of 6-7 rows 
of photoreceptor nuclei, preservation of photoreceptor outer segments and increase in thickness of outer nuclear layer and inner nuclear layer when compared to untreated rats which showed shorter photoreceptor outer and inner segments, thin outer nuclear layer with 2-3 rows of nuclei. Curcumin-treated transgenic rats showed increase in expression of rod-specific photoreceptor markers like rhodopsin and rod outer segment membrane protein (ROM-1) and cone-specific photoreceptor markers like S-Opsin Short wavelength and M-Opsin (medium wavelength) when compared to untreated rats. Electroretinography of transgenic rats treated with curcumin from P30-P70 showed the mean maximum scotopic a-wave amplitude in treated and untreated rats $(60.09 \mu \mathrm{V}$ vs $28.96 \mu \mathrm{V})$, mean maximum scotopic b-wave amplitude in treated and untreated rats $(264.8 \mu \mathrm{V}$ vs $96.39 \mu \mathrm{V})$, mean maximum photopic b-wave amplitude in treated and untreated rats $(61.3 \mu \mathrm{V}$ vs $32.95 \mu \mathrm{V})$, while the implicit time was unchanged in both the groups. Cryo sections of curcumin-treated $\mathrm{P} 23 \mathrm{H}-\mathrm{R}$ transgenic rats showed that curcumin can translocate rhodopsin to outer segment region when compared to untreated rats where it was located adjacent to few rows of nuclei in the outer nuclear layer. Curcumin-treated mutant rhodopsin-expressed cells showed decrease in expression endoplasmic reticulum stress proteins like $\mathrm{CHOP}$ and Grp78/Bip. Treatment of curcumin in retina of $\mathrm{P} 23 \mathrm{H}-$ $\mathrm{R}$ transgenic rats showed that both the endoplasmic reticulum stress genes showed reduced expression as the concentration increased to P30 [58].

Emoto et al. showed that $100 \mathrm{mg} / \mathrm{kg}$ and $200 \mathrm{mg} / \mathrm{kg}$ of curcumin, when administered to N-methyl N-nitrosourea (MNU)-induced photoreceptor cell apoptosis in rats, showed betterment in the loss of outer nuclear layer and photoreceptor cell layer in central retina in a dose-dependent manner. Curcumin at a dose of $200 \mathrm{mg} / \mathrm{kg}$ also improved photoreceptor cell survival when compared to $100 \mathrm{mg} / \mathrm{kg}$ and untreated group. The same dosage prevented retinal damage from central to peripheral retina 7 days after exposure to $\mathrm{MNU}$ in rats. A marker of retinal oxidative DNA damage 8-hydroxydeoxyguanosine $(8-\mathrm{OHdG})$ measured by ELISA was significantly reduced in those treated with $200 \mathrm{mg} / \mathrm{kg}$ of curcumin in MNU-exposed rats at $12 \mathrm{~h}$. $200 \mathrm{mg} / \mathrm{kg}$ of curcumin reduced the apoptotic cell ratio in the central retina at $12 \mathrm{~h}$ at which point the oxidative stress peaked [59].

Scott et al. studied the neuroprotective effect of curcumin by administering $100 \mathrm{mg} / \mathrm{kg}$ body weight/ day to embryonic transgenic mini swine and showed that curcumin prevented central-to-peripheral retinal pattern of thinning of outer nuclear layer and photo- receptor layer, abnormal changes to rod photoreceptor morphology and mislocalization of rhodopsin in rod photoreceptors when compared to untreated embryonic transgenic mini swine that showed significant thinning of outer retina, abnormal rod photoreceptor morphology and mislocalization of rhodopsin to outer nuclear layer [60].

\section{Proliferative vitreoretinopathy (PVR)}

The pathogenesis of PVR includes cell migration phase, wherein there is migration of RPE cells through the break, and contraction phase, wherein damage to blood-retinal barrier leads to exudation of fibrin, elastin, fibronectin, growth factors and cytokines and cell proliferation phase, which is evidenced by the formation of collagen which further pulls the retina by exerting traction. Growth factors like epidermal growth factor (EGF), transforming growth factor- $\beta$ (TGF- $\beta$ ), PDGF, hepatocyte growth factor, TNF- $\alpha$ and $\beta$ and cytokines like IL-1, IL-6, IL-8, interferon- $\Upsilon$ (INF- $\Upsilon$ ) have been raised in patients with PVR [61].

Sun et al. evaluated the role of curcumin in human RPE cell proliferation obtained by in vitro culture. These cells were treated with $15 \mu \mathrm{g} / \mathrm{ml}$ of curcumin and studied after 24, 48 and $72 \mathrm{~h}$. Curcumin inhibited $\mathrm{hRPE}$ cell proliferation in a dose- and time-dependent manner showing greater effects at $15 \mu \mathrm{g} / \mathrm{ml}$ than lower concentrations $(5 \mu \mathrm{g} / \mathrm{ml}$ or $10 \mu \mathrm{g} / \mathrm{ml})$ in the form of cell cycle arrest at G0/G1 phase, induction of apoptosis at early, mid- and late phases, increasing expression of P21 and P53 proteins but decreasing the levels of proliferating cell nuclear antigen (PCNA) protein levels [62]. Zhu et al. evaluated the role of various doses of curcumin $(10 \mu \mathrm{M}, 20 \mu \mathrm{M}, 40 \mu \mathrm{M}, 60 \mu \mathrm{M}, 100 \mu \mathrm{M})$ in aging ARPE19 cells (pulsed $\mathrm{H} 2 \mathrm{O} 2$ exposure aging model) in vitro. Aging cells had lower cell viability, higher apoptosis rates and more severe oxidative stress when compared to normal cells. Curcumin significantly improved cell viability, reduction of early and late apoptosis, upregulation of Bcl-2 (anti-apoptotic) and downregulation of Bax and caspase-3 (apoptotic), reduction of reactive oxygen species malondialdehyde (MDA) and upregulation of superoxide dismutase (SOD) and glutathione (GSH) in a dose- and timedependent manner [63].

Ren et al. used cultured rabbit RPE cells and detected EGF expression by immunocytochemistry and RPE cell proliferation by EGF in vitro at an optimal concentration of $9 \mathrm{ng} / \mathrm{ml}$ using 3-(4,5-dimethylthiazol2-yl)-2,5-biphenyl tetrazolium bromide (MTT) assay in a time-dependent manner. Immunocytochemistry also revealed EGF expression in the cytoplasm, which was significantly lower in the curcumin-treated group than in the control group. EGF expression decreased 
with increasing curcumin dose and increasing incubation time, and the optimal dosage of curcumin causing decrease in EGF was $15 \mu \mathrm{g} / \mathrm{ml}$. The EGF mRNA content by RT-PCR decreased by this dosage of curcumin over time. EGF protein expression in RPE cells by western blot analysis in the curcumin group decreased with time. Vitreous clouding seen by slit-lamp biomicroscopy and indirect ophthalmoscopy reduced in the curcumin group on day 7 and PVR membrane, which was graded using colour fundus photography, ultrasound B scan and indirect ophthalmoscopy, showed lower grading, being thin and lower incidence of retinal detachment $(11 \%$ vs $61 \%, 16 \%$ vs $75 \%$ and $16 \%$ vs $83 \%$ ) on days 14,21 and 28 post-treatment with curcumin [64].

\section{Retinal Ischemia-Reperfusion Injury (RIRI)}

This happens due to ocular hypertension or as a consequence of stroke in hypertension. The retinal ganglion cells are vulnerable to ischemia due to any cause and can lead to irreversible vision loss [13]. Liu et al. showed that heat shock transcription factor 1 (HSTF1) has been shown to play a vital role in promoting survival of cells under stressful circumstances that negated RIRI-induced neuronal apoptosis and necroptosis $12 \mathrm{~h}$ after RIRI in HSTF 1 transgenic mice. It gets upregulated in acute stages as a self-protective mechanism to prevent retinal damage [65]. Zhang et al. showed that in RIRI, there is increased expression of inflammatory mediators, interleukins IL-17 (peaked at $72 \mathrm{~h}$ ) and IL-23 (peaked at $24 \mathrm{~h}$ ) aggravating retinal injury in rat models. Curcumin at doses of $20 \mathrm{mg} / \mathrm{kg}$ / day and $100 \mathrm{mg} / \mathrm{kg} /$ day reduced the expression of IL-17 and IL-23 in a dose-dependent manner, thereby reducing RIRI-induced damage to retina [66]. RIRI induces increased $\mathrm{NF}_{\mathrm{K}} \mathrm{B}$ and signal transducer and activator of transcription 3 (STAT 3) in response to stress, which increases monocyte chemoattractant protein $1(\mathrm{MCP}-1)$ in rats. MCP-1 in turn causes retinal damage by recruiting inflammatory cells to the site of injury. Curcumin (oral curcumin in a dose of $0.05 \%$ and $0.25 \%$ ) before RIRI reduces vascular damage by nearly $40 \%$ which extends its action even 2 days after RIRI. Oral administration of curcumin $(0.01 \%, 0.05 \%$ and $0.25 \%$ - all 3 doses) inhibited RIRI-induced cell loss in ganglion cells 2 days after RIRI. Curcumin downregulates $\mathrm{NF}_{-} \mathrm{B}$ and STAT 3 and MCP- 1 consequentially and protects both retinal neurons and microvasculature as per Wang et al. [67].

Wang et al. evaluated the role of curcumin in retinal injury in stroke spontaneously hypertensive rats (SHR). This was obtained by electrocoagulation of bilateral vertebral artery along with transient common carotid artery ligation. In SHR rats, stroke caused apoptosis of retinal neurons and capillary cells due to the increased expression of c-Jun N-terminal kinase (JNK) and JNK-mediated activation of BAX (Bcl2 -associated $\mathrm{X}$ protein) and altering the stability of P53 protein. Curcumin when administered at $100 \mathrm{mg} /$ $\mathrm{kg}$ intraperitoneally $1 \mathrm{~h}$ before RIRI showed that it can prevent apoptosis in retinal capillary cells and subsequently hypertensive retinopathy after RIRI by inhibiting phosphorylated JNK-mediated actions [68].

The literature evidence, however, is not enough to support the action of curcumin and hence applied with caution.

\section{Retinal and choroidal tumours}

Retinoblastoma (RB) is due to mutation of RB1 gene which is a tumour-suppressor gene. Yu et al. showed that curcumin reduced viability of retinoblastoma (RB Y79) cells at $40 \mu \mathrm{M}$ (range $0-80 \mu \mathrm{M}$ for $24 \mathrm{~h}$ ) and caused G1 phase arrest $(0-80 \mu \mathrm{M}$ for $24 \mathrm{~h})$. It induced apoptosis of RBY79 cells through activation of caspase- 9 and caspase- 3 and mitochondrial membrane potential collapse in RBY79 cells (dose of $0-80 \mu \mathrm{M}$ for $24 \mathrm{~h}$ ). It induces the phosphorylation of JNK (c-Jun N-terminal kinase) and P38 MAPK (mitogenactivated protein kinase) which further enhanced the apoptosis of RBY79 cells (dose of $80 \mu \mathrm{M}$ for $24 \mathrm{~h}$ ) [69]. Li et al. showed that curcumin inhibited proliferation, migration, invasion and apoptosis of $\mathrm{Rb}$ cell lines RBY79 and SO-RB 50 through upregulation of mir-99a (micro-RNA-99a), which in turn inhibits the JAK/STAT (Janus kinases and signal transducer and activation of transcription proteins) pathway, which are a series of events involved in tumour formation (0-50 $\mu \mathrm{M}$ in a dose-dependent manner) [70]. Mukhopadhyay et al. showed that curcumin downregulates the activity of cyclin D 1-dependent kinase 4 (CDK4), which is responsible for phosphorylation of RB protein, cyclin D1 m-RNA, which is responsible for the synthesis of cyclin D1 and cyclin D1 promoter-dependent reporter gene expression, thereby substantiating its anti-proliferative effects in RB and other cancers. The dosage has been different for different cancers [71].

The above paragraph describes only cell lines and no animal models, and these various dosages for different cancers cannot give us strong evidence in favour of curcumin and hence have to be used with caution.

\section{Best Vitelliform Macular Dystrophy (BVMD)}

The mutation of human bestrophin- 1 (BEST-1) gene is responsible for causing bilateral macular disease in both adolescents and adults. This gene encodes a protein called human bestrophin- 1 that acts as a calcium-activated chloride channel that is greatly expressed in RPE. Mutation of BEST-1 gene causes reduced expression of its encoded protein that leads 
to protein structure impairment and downregulation of calcium-activated chloride channel expression, which in turn caused disturbance of intracellular calcium homeostasis, loss of tight junction protein ZO-1 and decreased phagocytic ability of RPE. There was always a question regarding the mechanism of the disease and a model to solve the questions regarding the pathogenesis, and drug screening was warranted. Patient-specific human-induced pluripotent stem cell (BVMD-iPSC) was developed from BVMD patientderived dental pulp stromal cells, which was then differentiated into BVMD-RPE cells. BVMD-RPE cells were used for in vitro candidate drug screening, and it replicated multiple pathogenetic mechanisms in BVMD. BVMD-RPE cells exhibited specific markers in the form of reduced expression of BEST-1 and ZO-1 and poor phagocytic potential when compared to unaffected sibling-derived iPSC-derived RPE cells. Curcumin-loaded nanoparticles $(\mathrm{Cu}-\mathrm{NP}-10 \mu \mathrm{M}$ for $72 \mathrm{~h}$ ) increased the expression of ZO-1, BEST-1, and suppressed hydrogen peroxide-induced ROS production and increased ROS scavenging, thereby promoting phagocytosis and increased expression of anti-oxidant enzymes providing a cytoprotective effect [72].

\section{Methyl alcohol intoxication of retina}

Seme et al. have demonstrated that in rats intoxicated with methanol in the presence of $\mathrm{N}_{2} \mathrm{O} / \mathrm{O}_{2}$, histopathological changes showed photoreceptor inner segment swelling and mitochondrial disruption and increased oxidative stress. This was hypothesized to be due to the toxic metabolite of methanol, i.e. formate. During recovery, there was partial improvement of rod-dominated responses but no improvement of UV cone-mediated responses [73]. Oral curcumin when administered for 4 weeks at a dosage of $2.5 \mathrm{mg} / \mathrm{kg} / \mathrm{day}$ in rats caused reversal of methanol-induced vacuolations in the photoreceptor inner segments and disaggregation of cells in the inner and outer nuclear retinal layers [15, 74].

\section{Central serous retinopathy (CSR)}

Curcumin when given in the form of oral phosphatidylcholine formulation had good oral availability. These Norflo tablets when given twice daily for a 6-month period in acute and chronic CSR in a pilot study of 18 eyes of 12 patients showed improvement in visual acuity in $61 \%$ of eyes and decreased detachment of retinal pigment epithelium in $78 \%$ of eyes. More randomized trials are, however, required to substantiate this [75].

\section{Cystoid macular oedema (CME)}

Allegri et al. studied the role of hydrophilic carrier of curcumin (Diabec) as an add-on treatment in recent onset noninfectious inflammatory CME. Curcumin was administered twice daily for 6 months with oral prednisolone $15 \mathrm{mg} /$ day $\pm 15 \mathrm{mg}$ methotrexate once a week and a control group without curcumin and only standard therapy. Out of 48, 25 eyes in curcumin-treated group showed reduction in central foveal thickness from $320( \pm 96.7) \mu \mathrm{m}$ to $283( \pm 46.3) \mu \mathrm{m}$ and control group showed no variations. Mean improvement in BCVA was 5.8 ETDRS letters in the curcumin group with no difference in the control group. These were preliminary results which will be assessed at 12 months [76].

Figure 3 shows the possible role of curcumin in treating retinal disorders.

\section{Curcumin in COVID era}

Liu et al. in their review have shown that pre-treatment with curcumin at various dosages of $5 \mathrm{mg} / \mathrm{kg} / \mathrm{day}$, $150 \mathrm{mg} / \mathrm{kg}$ for 15 days and $50 \mathrm{mg} / \mathrm{kg} /$ day have reduced inflammation, acute lung injury-induced pneumonia and subsequent fibrosis in paraquat-induced lung inflammation, Klebsiella and reo virus-induced lung damage, respectively, in animal models. This has been attributed to the downregulation of pro-inflammatory cytokines such as interleukin-1 (IL-1), IL-6, IL-8, TNF- $\alpha$ and upregulation of anti-inflammatory cytokines like IL-10. Curcumin directly scavenges ROS through indirect enzymatic regulation of SOD2, which plays an important role in maintaining oxidant-anti-oxidant balance [77]. Studies have shown that curcumin has strong affinity for S-protein and angiotensin-converting enzyme-2 (ACE-2) receptor and its complex, thereby directly targeting viral proteins inhibiting particle production and gene expression, blocking the entry of the virus, its replication and budding. This computational study showed the binding affinity of catechin and curcumin for S-protein, ACE-2 receptor and its complex to be -10.5 and $-7.9 \mathrm{kcal} / \mathrm{mol}$, -8.9 and $-7.8 \mathrm{kcal} / \mathrm{mol}$ and -9.1 and $7.6 \mathrm{kcal} / \mathrm{mol}$, respectively [78]. Investigators studied the extenuating effect of curcumin on thrombosis by its anti-coagulant and antiplatelet activity both in vitro and in vivo. Pre-treatment with $45 \mathrm{mg} / \mathrm{kg}$ of curcumin or $200 \mu \mathrm{l}$ of vehicle alone $1 \mathrm{~h}$ before in diesel exhaust particle (DEP)-induced mice prevented the increase of $\mathrm{D}$-dimer and plasminogen activator inhibitor-1 (PAI-1) along with prevention of increase of CRP, TNF- $\alpha$ and systolic blood pressure. This was further supported by Kim et al. who demonstrated that curcumin and bisdemethoxycurcumin prolonged activated partial thromboplastin time (APTT) and prothrombin time (PT) and inhibited thrombin and activated factor $\mathrm{x}$ both in vitro and in vivo at or concentration greater than $5 \mu \mathrm{M}$ [79-81]. Lot of evidence has already emerged regarding the action of curcumin in SARS-associated corona virus (SARS CO-V) by directly interacting with viral 


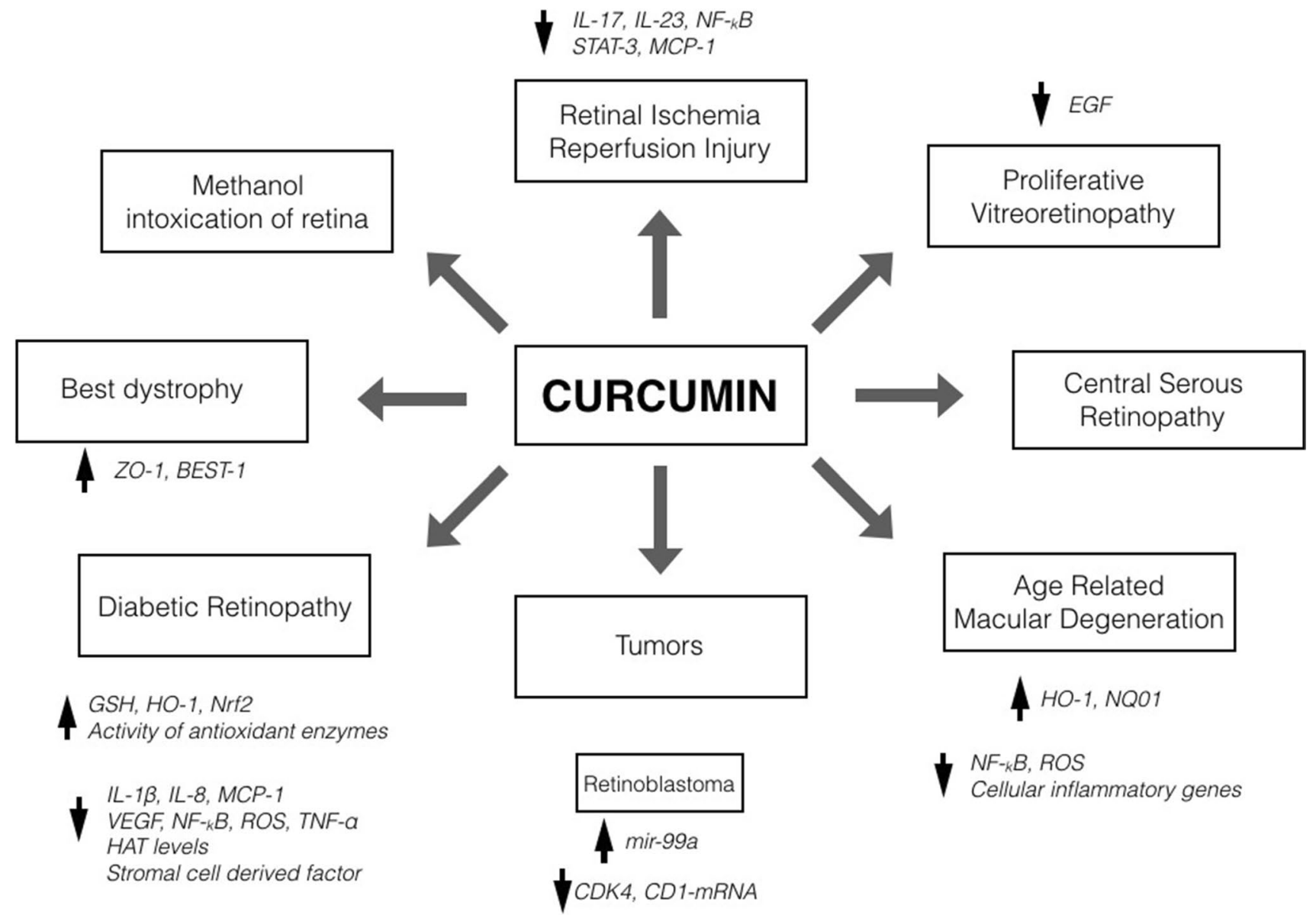

Fig. 3 Possible mechanism of curcumin in various retinal diseases. (IL- 8, IL-17, IL-23, IL-1 $\beta$ Interleukin -8, Interleukin - 17, Interleukin - 23, Interleukin $1 \beta, \mathrm{NF}_{\mathrm{K}} \mathrm{B}$ - Nuclear Factor Kappa B, STAT 3 - Signal Transducer and Activation of Transcription 3, MCP-1 Monocyte Chemoattractant Protein- 1, EGF - Epidermal Growth Factor, HO-1 - Haemoxygenase -1, NQO-1- NADPH Quinone Dehydrogenase - 1, ROS - Reactive Oxygen Species, BAX - Bcl-2 associ-

proteins, disrupting the viral envelope, inhibiting viral proteases and modulating $\mathrm{NF}_{\mathrm{K}} \mathrm{B}, \mathrm{Nrf} 2$ and high mobility group box 1(HMGB1) pathways in vitro. SARS-CoV-2 (COVID-19) has nearly $79 \%$ resemblance to SARS CO-V and hence the postulation [82].

The above-mentioned studies show the possible mechanisms and pleiotropic effects of curcumin in animal models. We should also look for reproducibility of its effects in humans and the right dosage that can be used as a therapeutic option in humans. It should be clearly understood that curcumin can never be a replacement for the vaccine and can be tried as an adjunct therapeutic agent or as a natural medicine.

The following figure shows the possible mechanisms of curcumin in combating the COVID virus at various stages of the disease (Fig. 4). ated X-Protein, Bcl-2 - B-Cell Lymphoma- 2, mir -99a - microRNA 99a, CDK4 - Cycline D1 dependent Kinase 4, CD1 mRNA - Cycline D1 mRNA, VEGF- Vascular Endothelial Growth Factor, TNF - $\alpha$ - Tumour Necrosis Factor - $\alpha$, HAT - Histone Acetyl Transferase, GSH - Glutathione, Nrf2-Nuclear factor erythroid-2 related factor-2, ZO-1 - Zonula Occludens -1)

\section{Retinal distribution of curcumin}

Platania et al. studied the retinal distribution of three commercial products of curcumin-curcumin with a polyvinyl pyrrolidine-hydrophilic carrier (CHC), with phosphatidyl complex (CPC) and with piperine (CPI) in vivo in white rabbits that were given curcumin orally. Rabbits received single dose of $5 \mathrm{mg} / \mathrm{kg}$ by oral lavage after sedation. Retinal distribution of curcumin was assessed at various time points $(0,2,6,12$ and $24 \mathrm{~h})$ after oral administration. Only the hydrophilic carrier form reached rabbit retina, the maximum serum concentration $\left(\mathrm{C}_{\max }\right)$ of $\mathrm{CHC}$ was $0.036 \pm 0.002$, time taken for the drug to reach its maximum concentration $\left(\mathrm{T}_{\max }\right)$ for $\mathrm{CHC}$ was $6 \mathrm{~h}$, and area under the curve (AUC - the definite integral of a curve that 


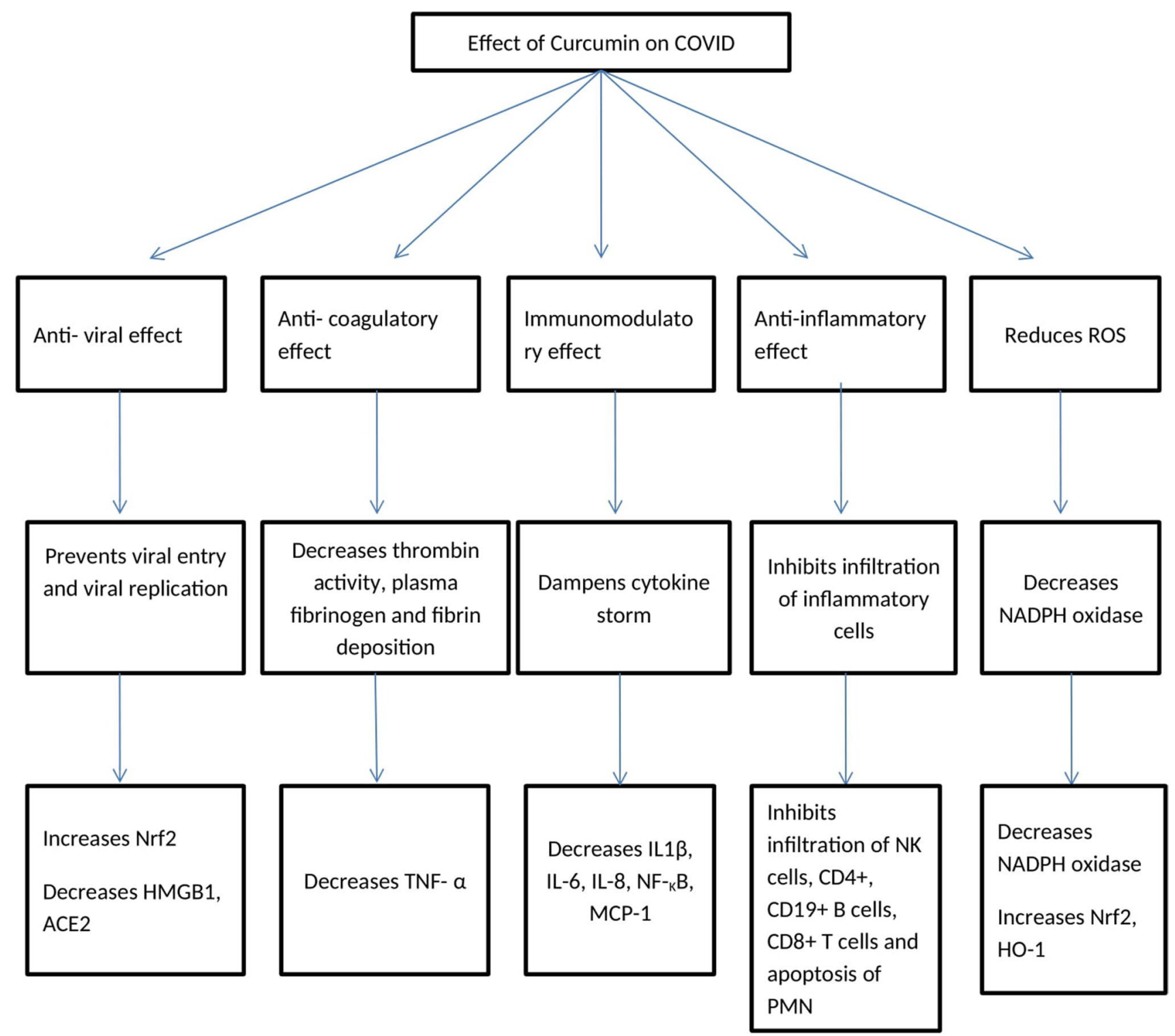

Fig. 4 Mechanism of curcumin in reducing viral replication, cytokine storm and its immunomodulatory effect and anti-coagulant effect. (NADPH oxidase - Nicotinamide Adenine Dinucleotide Phosphate oxidase, HMGB1 - High Mobility Group Protein B1, ACE2 - Angiotensin Converting Enzyme 2, NK cells - Natural Killer cells, CD Cluster of Differentiation, PMN- Polymorphonuclear leucocytes) describes the variation of the drug concentration in plasma as a function of time) was $15.48 \pm 0.05 \mathrm{ng}^{*} / \mathrm{min} / \mathrm{mg}$. Curcumin significantly stopped ROS production $(p<0.05)$ in ARPE-19 cells that were exposed to oxidative stress (hydrogen peroxide-induced) at lower concentration of $1 \mu \mathrm{M}$ and reduced TNF- $\alpha$ in HREC cells that were exposed to high glucose at a dose of $10 \mu \mathrm{M}[46,83]$.

\section{Safety profile of curcumin in humans}

Cheng et al. studied the pharmacokinetics, toxicology and biologically effective dose of curcumin in humans with high risk or premalignant lesions. An initial dose of $500 \mathrm{mg}$ once a day in empty stomach in 25 patients and the 
dose was increased to $1000,2000,4000,8000$ and 12,000 if there was no toxicity $\geq$ grade 2 in at least 3 successive patients. No toxicity was seen in doses up to $8000 \mathrm{mg}$. However, $12,000 \mathrm{mg}$ was not acceptable by patients because of the bulky nature of the tablet. The serum concentration peaked at $1-2 \mathrm{~h}$ of intake but declined gradually within $24 \mathrm{~h}$ with barely detectable serum concentration up to $2000 \mathrm{mg}$, and urinary excretion was undetectable. The $\mathrm{C}_{\max }$ of 4000,6000 and 8000 was $0.51 \pm 0.11 \mu \mathrm{M}$, $0.63 \pm 0.06 \mu \mathrm{M}$ and $1.77 \pm 1.87 \mu \mathrm{M}$, respectively. Curcumin showed no toxicity up to $8000 \mathrm{mg}$ when taken for 3 months. Though 1 patient each with CIN and leucoplakia developed frank malignancies, there was histological improvement in some of them [84].

To study the maximum-tolerated dose and safety of curcumin, Lao conducted a study in eligible study participants (24 subjects) who were 18 years or older and who had not consumed curcumin-rich food in the last 14 days. A dose escalation of 500-12,000 mg of standardized curcumin was administered, and safety was assessed for $72 \mathrm{~h}$, which showed 7 adverse events that were grade 1 (diarrhoea, rash, headache and yellow stool) according to National cancer institute, common toxicity criteria version 2.0. There was no dose-related toxicity. Only curcumin at doses of 10,000 and $12,000 \mathrm{mg}$ in 2 subjects showed serum concentration. This low-serum concentration partly might be due to extensive intestinal and hepatic metabolic biotransformation [85].

\section{Summary}

Curcumin is a spice that is available easily and is affordable. It is edible and can be consumed in large quantities in food. There are only a few literature evidence that exists for few retinal diseases, and hence, the reproducibility of such observations remains a question. It is imperative to establish a proper dosage that will produce the desired effects in humans akin to animal models. It would be a challenge to investigate whether large quantities that are consumed are enough to produce the required amount of serum concentration to treat retinal diseases. The dosage may be different for different retinal diseases though. The solubility, bioavailability and stability of curcumin can be improved by using carriers and newer formulations of curcumin. Curcumin also seems to have favourable safety profile, but this small evidence may not be enough to translate into humans particularly for retinal diseases. However, it should be clearly understood that curcumin can never replace the vaccine and can only be considered as an alternative therapeutic agent, provided the results are reproducible in humans or human concentrations in cell culture experiments. Results of its actions and efficacy in retinal diseases in humans are at the experimental level with a lot of scope for future research.
More randomized controlled clinical trials with a large cohort are required to establish its efficacy and safety in humans, but there is still a long way to go before establishing its true therapeutic role in retinal diseases.

\section{Declarations}

Presentation at a conference No.

Conflict of interest Nil.

Financial Disclosure Nil.

Research involving human participants and/or animals Nil.

\section{References}

1. Beatty S, Koh H, Phil M, Henson D, Boulton M (2000) The Role of Oxidative Stress in the Pathogenesis of Age-Related Macular Degeneration. Surv Ophthalmol 45(2):115-134

2. Arnal E, Miranda M, Johnsen-Soriano S, Alvarez-Nlting R, Daz-Llopis M, Araiz J, Cervera E, Bosch-Morell F, Romero FJ (2009) Beneficial effect of docosahexanoic acid and lutein on retinal structural, metabolic, and functional abnormalities in diabetic rats. Curr Eye Res 34:928-938

3. Yang Y, Qin YJ, Yip YWY, Chan KP, Chu KO, Chu WK, Ng TK, Pang CP, Chan SO (2016) Green tea catechins are potent anti-oxidants that ameliorate sodium iodate-induced retinal degeneration in rats. Sci Rep 6:29546

4. Di Marco S, Carnicelli V, Franceschini N, Di Paolo M, Piccardi M, Bisti S, Falsini B (2019) Saffron: A Multitask Neuroprotective Agent for Retinal Degenerative Diseases. Antioxidants $8(7): 224$

5. Martínez-Solís I, Acero N, Bosch-Morell F, Castillo E, GonzálezRosende ME, Muñoz-Mingarro D, Ortega T, Sanahuja MA, Villagrasa V (2019) Neuroprotective Potential of Ginkgo biloba in Retinal Diseases. Planta Med 85(17):1292-1303

6. Krishnaswamy K (2008) Traditional Indian spices and their health significance. Asia Pac J Clin Nutr 17(Suppl 1):265-268

7. Miriyala S, Panchatcharam M, Rengarajulu P (2007) Cardioprotective effects of curcumin. Adv Exp Med Biol 595:359-377

8. Cole GM, Teter B, Frautschy SA (2007) Neuroprotective effects of curcumin. Adv Exp Med Biol 595:197-212

9. Allegra A, Innao V, Russo S, Gerace D, Alonci A, Musolino C (2017) Anticancer activity of curcumin and its analogues: preclinical and clinical studies. Cancer Invest 35(1):1-22

10. Noorafshan A, Ashkani-Esfahani S (2013) A review of therapeutic effects of curcumin. Curr Pharm Des 19(11):2032-2046

11. Franzone F, Nebbioso M, Pergolizzi T, Attanasio G, Musacchio A, Greco A, Limoli PG, Artico M, Spandidos DA, Taurone S, Agostinelli E (2021) Anti-inflammatory role of curcumin in retinal disorders (Review). Exp Ther Med 22(1):790

12. Farajipour H, Rahimian S, Taghizadeh M (2018) Curcumin: A new candidate for retinal disease therapy? J Cell Biochem 2018:18. https://doi.org/10.1002/jcb. 28068

13. López-Malo D, Villarón-Casares CA, Alarcón-Jiménez J, Miranda M, Díaz-Llopis M, Romero FJ, Villar VM (2020) Curcumin as a Therapeutic Option in Retinal Diseases. Antioxidants 9(1):48. https://doi.org/10.3390/antiox9010048 
14. Peddada KV, Brown A, Verma V, Nebbioso M (2019) Therapeutic potential of curcumin in major retinal Pathologies. Int Ophthalmol 39(3-4). https://doi.org/10.1007/s10792-018-0845-y

15. Wang LL, Sun Y, Huang K, Zheng L (2013) Curcumin, a potential therapeutic candidate for retinal diseases. Mol Nutr Food Res 57(9):1557-1568. https://doi.org/10.1002/mnfr.201200718

16. Hanai H, Sugimoto K (2009) Curcumin has bright prospects for the treatment of inflammatory bowel disease. Curr Pharm Des 15(18):2087-2094. https://doi.org/10.2174/138161209788489177

17. Gonzalez-Salazar A, Molina-Jijon E, Correa F, Zarco- Marquez G, Calderon Oliver M, Tapia E, Zazueta C, Pedraza- Chaverri J (2011) Curcumin protects from cardiac reperfusion damage by attenuation of oxidant stress and mitochondrial dysfunction. Cardiovasc Toxicol 11(4):357-364

18. Hybertson BM, Gao B, Bose SK, McCord JM (2011) Oxidative stress in health and disease: the therapeutic potential of Nrf2 activation. Mol Aspects Med 32(4-6):234-246

19. Balogun E, Hoque M, Gong P, Killeen E, Green CJ, Foresti R, Alam J, Moterlini R (2003) Curcumin activates the haem oxygenase-1 gene via regulation of $\mathrm{Nrf} 2$ and the antioxidant-responsive element. Biochem J 371(pt 3):887-895

20. Sreejayan RMN (1997) Nitric oxide scavenging by curcuminoids. J pharm Pharmacol 49(1):105-107. https://doi.org/10.1111/j. 2042-7158.1997.tb06761.x

21. Marcu MG, Jung YJ, Lee S, Chung EJ, Lee MJ, Trepel J, Neckers L (2006) Curcumin is an Inhibitor of p300 Histone Acetyltransferase. Med Chem 2(2):169-174

22. Bhandarkar SS, Arbiser JL (2007) Curcumin as an inhibitor of angiogenesis. Adv Exp Med Biol 595:185-195. https://doi.org/ 10.1007/978-0-387-46401-5_7

23. Baker M (2017) Deceptive curcumin offers cautionary tale for chemists. Nature 541(7636):144-145

24. Bisson J, McAlpine JB, Friesen JB, Chen SN, Graham J, Pauli GF (2016) Can Invalid Bioactives Undermine Natural Product-Based Drug Discovery? J Med Chem 59(5):1671-1690

25. Li M, Xin M, Guo C, Lin G, Wu X (2017) New nanomicelle curcumin formulation for ocular delivery: Improved stability, solubility, and ocular anti-inflammatory treatment. Drug Dev Ind Pharm 43(11):1846-1857

26. Barenholz Y (2012) Doxil ${ }^{\circledR}$ - the first FDA-approved nano-drug: Lessons learned. J Control Release 160(2):117-134

27. Chen Y, Lu Y, Lee RJ, Xiang G (2020) Nano encapsulated curcumin: and its potential for biomedical applications. Int J Nanomedicine 15:3099-3120

28. Zhang J, Sun H, Zhou N, Zhang B, Ma J (2017) Preparation and evaluation of biodegradable scleral plug containing curcumin in rabbit eye. Curr Eye Res 42:1597-1603

29. Mazzolani F, Togni S, Giacomelli L, Eggenhoffner R, Franceschi F (2018) Oral administration of a curcumin-phospholipid formulation (Meriva $\left.{ }^{\circledR}\right)$ for treatment of chronic diabetic macular edema: A pilot study. Eur Rev Med Pharmacol Sci 22(11):3617-3625

30. Granata G, Paterniti I, Geraci C, Cunsolo F, Esposito E, Cordaro M, Blanco AR, Cuzzocrea S, Consoli GML (2017) Potential Eye Drop Based on a Calix[4]arene Nanoassembly for Curcumin Delivery: Enhanced Drug Solubility, Stability and Anti-Inflammatory E_ect. Mol Pharm 14(5):1610-1622

31. Davis BM, Pahlitzsch M, Guo L, Balendra S, Shah P, Ravindran N, Malaguarnera G, Sisa C, Shamsher E, Hamze H, Noor A, Sornsute A, Somavarapu S, Cordeiro MF (2018) Topical Curcumin Nanocarriers are Neuroprotective in Eye Disease. Sci Rep 8(1):11066

32. Cheng YH, Ko YC, Chang YF, Huang SH, Ling LCJ (2019) Thermosensitive chitosan-gelatin-based hydrogel containing curcuminloaded nanoparticles and latanoprost as a dual-drug delivery system for glaucoma treatment. Exp Eye Res 179:179-187
33. Kim D, Maharjan P, Jin M, Park T, Maharjan A, Amatya R, Yang J, Min KA, Shin M (2019) Potential Albumin-Based Antioxidant Nanoformulations for Ocular Protection against Oxidative Stress. Pharmaceutics 11(7):297

34. Maharjan P, Jin M, Kim D, Yang JW, Maharjan A, Shin MC, Cho KH, Kim MS, Min KA (2019) Evaluation of epithelial transport and oxidative stress protection of nanoengineered curcumin derivative-cyclodextrin formulation for ocular delivery. Arch Pharm Res 42:909-925

35. Wang J, Zhou J, He H, Wu D, Du X, Xu B, Xiong T, Li X (2018) Enzymatic formation of curcumin in vitro and in vivo. Nano Res 11(6):3453-3461

36. Muangnoi $\mathrm{C}$, Sharif U, Ratnatilaka Na Bhuket P, Rojsitthisak $P$, Paraoan L (2019) Protective Effects of Curcumin Ester Prodrug, Curcumin Diethyl Disuccinate against H2O2-Induced Oxidative Stress in Human Retinal Pigment Epithelial Cells: Potential Therapeutic Avenues for Age-Related Macular Degeneration. Int J Mol Sci 20(13):3367

37. Pittalà V, Salerno L, Fidilio A, Lazzara F, Platania CBM, Drago F, Bucolo C, Foresti R (2017) Effects of Novel Nitric Oxide-Releasing Molecules against Oxidative Stress on Retinal Pigmented Epithelial Cells. Oxidative Med Cell Longev. https://doi.org/10.1155/ 2017/1420892

38. Shoba G, Joy D, Joseph T, Majeed M, Rajendran R, Srinivas PS (1998) Influence of piperine on the pharmacokinetics of curcumin in animals and human volunteers. Planta Med 64(4):353-356

39. Kowluru RA, Chan P-S (2007) Oxidative Stress and Diabetic Retinopathy. Exp Diabetes Res 2007:43603. https://doi.org/10. 1155/2007/43603

40. Chiu J, Xu BY, Chen S, Feng B, Chakrabarti S (2008) Oxidative stress-induced, poly (ADP-ribose) polymerase-dependent upregulation of ET-1 expression in chronic diabetic complications. Can J Physiol Pharmacol 86(6):365-372

41. Kowluru RA, Kanwar M (2007) Effects of curcumin on retinal oxidative stress and inflammation in diabetes. Nutr Metab (Lon) 4:8. https://doi.org/10.1186/1743-7075-4-8

42. Gupta SK, Kumar B, Nag TC, Agrawal SS, Agrawal R, Agrawal P, Saxena R, Srivastava S (2011) Curcumin prevents experimental diabetic retinopathy in rats through its hypoglycemic, antioxidant, and anti-inflammatory mechanisms. J Ocul Pharmacol Ther 27(2):123-130

43. Khimmaktong W, Petpiboolthai H, Sriya P, Anupunpisit V (2014) Effects of curcumin on restoration and improvement of microvasculature characteristic in diabetic rat's choroid of eye. J Med Assoc Thai 97(Suppl 2):S39-46

44. Wang C, George B, Chen S, Feng B, Li X, Chakrabarti S (2012) Genotoxic stress and activation of novel DNA repair enzymes in human endothelial cells and in the retinas and kidneys of streptozotocin diabetic rats. Diabetes Metab Res Rev 28(4):329-337

45. Sameermahmood Z, Balasubramanyam M, Saravanan T, Rema M (2018) Curcumin modulates SDF- alpha/CXCR4- induced migration of human retinal endothelial cells (HRECs). Invest Ophthalmol Vis Sci 49:3305-3311

46. Platania CBM, Fidilio A, Lazzara F, Piazza C, Geraci F, Giurdanella G, Leggio GM, Salomone S, Drago F, Bucolo C (2018) Retinal protection and distribution of curcumin in vitro and in vivo. Front Pharmacol 9:670

47. Premanand C, Rema M, Sameer MZ, Sujatha M, Balasubramanyam M (2006) Effect of curcumin on proliferation of human retinal endothelial cells under in vitro conditions. Invest Ophthalmol Vis Sci 47(5):2179-2184

48. Bucolo C, Drago F, Maisto R, Romano GL, D'Agata V, Maugeri G, Giunta S (2019) Curcumin prevents high glucose damage in retinal pigment epithelial cells through ERK1/2-mediated activation of the Nrf2/HO-1 pathway. J Cell Physiol 234:17295-17304 
49. Mandal MNA, Patlolla JMR, Zheng L, Agbaga M-P, Tran J-TA, Wicker L, Kasus-Jacobi A, Elliott MH, Rao CV, Anderson RE (2009) Curcumin protects retinal cells from light-and oxidant stress-induced cell death. Free Radic Biol Med 46(5):672-679

50. Chang Y-C, Chang W-C, Hung K-H, Yang D-M, Cheng Y-H, Liao Y-W, Woung L-C, Tsai C-Y, Hsu C-C, Lin T-C, Liu J-H, Chiou S-H, Peng C-H, Chen S-J (2014) The generation of induced pluoripotent stem cells for macular degeneration as a drug screening platform: identification of curcumin as a protective agent for retinal pigment epithelial cells against oxidative stress. Front Aging Neurosci 6(191):1-12. https://doi.org/10. 3389/fnagi.2014.00191

51. Park S, Lee EH, Kim SR, Jang YP (2016) Anti-apoptotic effect of Curcuma Longa L. extract and its cur uminoids against blue light induced cytotoxicity in A2E-laden human retinal pigment epithelial cells. J Pharm Pharmacol 69(3):334-340. https://doi. org/10.1111/jphp.12691

52. Bhattacharjee S, Zhao Y, Dua P, Rogeav EI, Lukiv WJ (2016) Micro RNA 34a-mediated downregulation of the microglialenriched triggering receptor and phagocytosis-sensor TREM-2 in age-related macular degeneration. PLoS ONE 11(3):e0150211. https://doi.org/10.1371/journal.pone.0150211

53. Kakouri A, Pfahler N, Bielskus I, Giovingo M, Aman S, Zaparackas Z, Knepper PA (2021) Slowing the progression of geographic atrophy with oral resveratrol, quercetin and curcumin. Investig Ophthalmol Vis Sci 62:332

54. Barry JL, Pfahler NM, Kakouri A, Bielskus I, Giovingo M, Aman S, Zararackas Z, Knepper PA (2020) Curcumin hot spots: A biphasic event in AMD drusen. Investig Ophthalmol Vis Sci 61:2996

55. Bielskus I, Kakouri A, Pfahler NM, Barry JL, Aman S, Zararackas Z, Volpe NJ, Knepper PA (2020) Curcumin acts to regress macular drusen volume in dry AMD. Investig Ophthalmol Vis Sci 61:1036

56. Beilskus I, Pfahler N, Kakouri A, Aman S, Zaparackas Z, Knepper PA (2021) Can drusen growth in age-related macular degeneration be slowed by oral curcumin? Investig Ophthalmol Vis Sci 62:330

57. Saliba RS, Munro PM, Luthert PJ, Cheetham ME (2002) The cellular fate of mutant rhodopsin: Quality control, degradation and aggresome formation. J Cell Sci 115(PT 14):2907-2918

58. Vasireddy V, Chavali VR, Joseph VT, Kadam R (2011) Rescue of photoreceptor degeneration by curcumin in transgenic rats with P23H rhodopsin mutation. PLoS ONE 6(6):e21193. https://doi. org/10.1371/journal.pone.0021193

59. Emoto Y, Yoshizawa K, Uehara N, Kinoshita Y, Yuri T, Shikata N, Tsubura A (2013) Curcumin suppresses n-methyl-n-nitrosoureainduced photoreceptor apoptosis in sprague-dawley rats. In Vivo 27:583-590

60. Scott PA, Kaplan HJ, McCall MA (2015) Prenatal Exposure to Curcumin Protects Rod Photoreceptors in a Transgenic Pro23His Swine Model of Retinitis Pigmentosa. Transl Vis Sci Technol 4(5):5. https://doi.org/10.1167/tvst.4.5.5

61. Leiderman YI, Miller JW (2009) Proliferative vitreoretinopathy: pathobiology and therapeutic targets. Semin Ophthalmol 24(2):62-69. https://doi.org/10.1080/08820530902800082

62. Sun Y, You ZP (2014) Curcumin inhibits human retinal pigment epithelial cell proliferation. Int J Mol Med 34:1013-1019

63. Zhu W, Wu Y, Meng YF, Wang JY, Xu M, Tao JJ, Lu J (2015) Effect of curcumin on aging retinal pigment epithelial cells. Drug Des Dev Ther 2015(9):5337-5344

64. Ren YX, Ma JX, Zhao F, An JB, Geng YX, Liu LY (2018) Effects of Curcumin on Epidermal Growth Factor in Proliferative Vitreoretinopathy. Cell Physiol Biochem 47(5):2136-2146

65. Liu W, Xia F, Ha Y, Zhu S, Li Y, Folorunso O, Pashaei-Marandi A, Lin PY, Tilton RG, Pierce AP, Liu H, Zhang W (2019) Neuroprotective effects of HSF1 in retinal ischemia-reperfusion injury. Investig Ophthalmol Vis Sci 60:965-977
66. Zhang HJ, Xing YQ, Jin W, Li D, Wu K, Lu Y (2015) Effects of curcumin on interleukin-23 and interleukin-17 expression in rat retina after retinal ischemia-reperfusion injury. Int J Clin Exp Pathol 8(8):9223-9231

67. Wang L, Li C, Guo H, Kern TS, Huang K, Zheng L (2011) Curcumin inhibits neuronal and vascular degeneration in retina after ischemia and reperfusion injury. PLoS ONE 6(8):e23194

68. Wang S, Ye Q, Tu J, Zhang M, Ji B (2017) Curcumin protects against hypertension aggravated retinal ischemia/reperfusion in a rat stroke model. Clin Exp Hypertens 39(8):711-717

69. Yu X, Zhong J, Yan L, Li J, Wang H, Wen Y, Zhao Y (2016) Curcumin exerts antitumor effects in retinoblastoma cells by regulating the JNK and p38 MAPK pathways. Int J Mol Med 38(3):861-868

70. Li Y, Sun W, Han N, Zou Y, Yin D (2018) Curcumin inhibits proliferation, migration, invasion and promotes apoptosis of retinoblastoma cell lines through modulation of miR-99a and JAK/ STAT pathway. BMC Cancer 18:1230. https://doi.org/10.1186/ s12885-018-5130-y

71. Mukhopadhyay A, Banerjee S, Stafford LJ, Xia C, Liu M, Aggarwal BB (2002) Curcumin-induced suppression of cell proliferation correlates with down-regulation of cyclin D1 expression and CDK4-mediated retinoblastoma protein phosphorylation. Oncogene 21(57):8852-8861

72. Lin T-C, Lin Y-Y, Hsu C-C, Yang Y-P, Yang C-H, Hwang D-K, Wang C-Y, Liu Y-Y, Lo W-L, Chiou S-H, Peng C-H, Chen S-J and Chang Y-L (2019) Nanomedicine-based Curcumin Approach Improved ROS Damage in Best Dystrophy-specific Induced Pluripotent Stem Cells. Cell Transplant 1-13https://doi.org/10.1177/ 0963689719860130

73. Seme MT, Summerfelt P, Neitz J, Eells JT, Henry MM (2001) Differential recovery of retinal function after mitochondrial inhibition by methanol intoxication. Invest Ophthalmol Vis Sci 42(3):834-841

74. Chirapapaisan N, Uiprasertkul M, Chuncharunee A (2012) The effect of coenzyme Q10 and curcumin on chronic methanol intoxication induced retinopathy in rats J Med Assoc Thai 95 Suppl 4:S76-81.

75. Mazzolani F (2012) Pilot study of oral administration of a curcumin-phospholipid formulation for treatment of central serous chorioretinopathy. Clin Ophthalmol 6:801-806

76. Allegri P, Rissotto R, Rissotto F, Masala A, Crivelli MG, Blanco AR, Murialdo U (2020) Evaluation of the anti-inflammatory efficacy of high oral bioavailability curcumin as add-on treatment in non-infectious uveitic cystoid macular edema by SD-OCT and OC-angiography: preliminary results. Investig Ophthalmol Vis Sci 61:5356

77. Liu Z, Ying Y (2020) The inhibitory effect of curcumin on virusinduced cytokine storm and its potential use in the associated severe pneumonia. Frontiers in Cell and Developmental Biology 8:479. https://doi.org/10.3389/fcell.2020.00479

78. Jena AB, Kanungo N, Nayak V, Chainy GBN, Dandapat J (2021) Catechin and curcumin interact with $S$ protein of SARS-CoV2 and ACE2 of human cell membrane: insights from computational studies. Scientific reports 11(10):2043

79. Nemmar A, Subramaniyan D, Ali BH (2012) Protective Effect of Curcumin on Pulmonary and Cardiovascular Effects Induced by Repeated Exposure to Diesel Exhaust Particles in Mice. Plos One 7(6):e39554

80. Kim D-C, Ku S-K, Bae J-S (2012) Anticoagulant activities of curcumin and its derivative. BMB Rep 45(4):221-226

81. Padmanabhan S, Suresh (2020) Curcumin and Coagulopathy in the COVID19 Era. Ind J Clin Biochem 35(4):504-505https://doi. org/10.1007/s12291-020-00914-5

82. Thimmulappa RK, Nagaraju KKM, Shivamallu C, Subramaniam KJT, Radhakrishnan A, Bhojraj S, Kuppusamy G (2021) Antiviral 
and immunomodulatory activity of curcumin: A case for prophylactic therapy for COVID-19. Heliyon 7(2):e06350

83. Bucolo C, Platania CBM, Fidilio A, Lazzara F, Piazza C, Geraci F, Salomone S, Drago F (2018) Retinal bioavailability of different curcumin oral formulations: A translational study. Investig Ophthalmol Vis Sci 59:193

84. Cheng AL, Hsu CH, Lin JK, Hsu MM, Ho YF, Shen TS, Ko JY, Lin JT, Lin BR, Ming-Shiang W, Yu HS, Jee SH, Chen GS, Chen TM, Chen CA, Lai MK, Pu YS, Pan MH, Wang YJ, Tsai CC, Hseih CY (2001) Phase I clinical trial of curcumin, a chemo-preventive agent in patients with high-risk or pre-malignant lesions. Anticancer Res 21(4B):2895-2900

\section{Authors and Affiliations}

\section{Priya R. Chandrasekaran ${ }^{1}$ (D) V. G. Madanagopalan ${ }^{2} \mathbb{D}$}

1 Consultant, Department of Medical Retina, Uvea, Neuroophthalmology, Lotus Eye Hospital, Brindavan Road, Salem-636016, Tamil Nadu, India
85. Lao CD, Ruffin MT IV, Normolle D, Heath DD, Murray SI, Bailey JM, Boggs ME, Crowel J, Rock CL, Brenner DE (2006) Dose escalation of a curcuminoid formulation. BMC complimentary and alternative medicine $6(10): 1-4$

Publisher's Note Springer Nature remains neutral with regard to jurisdictional claims in published maps and institutional affiliations.
2 Director Vitreo-Retina Services, JB Eye Care and Retina Centre, Sarada College Road, Salem-636007, Tamil Nadu, India 